\title{
1 The impact of housing conditions on porcine adult \\ 2 stem cell populations differ between adipose tissue \\ 3 and skeletal muscle
}

4

5

6 Audrey Quéméner, Frédéric Dessauge, Marie-Hélène Perruchot, Nathalie Le

7 Floc'h, Isabelle Louveau

8

9 PEGASE, INRAE, Institut Agro, Saint Gilles, France

10

11 Corresponding author:

12 Isabelle Louveau

1316 Le Clos, 35590 Saint Gilles, France

14 Email address: isabelle.louveau@inrae.fr 


\section{Abstract}

32 Background. In pigs, the ratio between lean mass and fat mass determines production efficiency and is strongly influenced by the number and size of cells in tissues. During growth, the increase in the number of cells results from the recruitment of different populations of multipotent adult stem cells residing in the tissues. We hypothesized that the impact of a hygiene challenge on the proportions of adult stem cells in adipose tissue and skeletal muscle may differ between pigs with different residual feed intake (RFI), a measure of feed efficiency.

Methods. At the age of 11 weeks, Large White pigs from two lines divergently selected for low and high RFI were housed in two contrasting hygiene conditions (good vs poor). After six weeks of challenge, pigs were slaughtered ( $n=5-9 /$ group). Samples of subcutaneous adipose tissue and longissimus muscle were collected, and cells from the stromal vascular fraction (FSV), which includes adult stem cell populations, were isolated from each tissue. Adipose and muscle cell populations from the FSV were phenotyped by flow cytometry using antibodies that targeted different cell surface markers (CD45 to identify hematopoietic cells; CD34, CD38, CD56 and CD140a to identify mesenchymal stem cells (MSC) with adipogenic and/or myogenic potential).

Results. Adipose tissue and muscle shared some common MSC populations although MSC diversity was higher in muscle than in adipose tissue. In muscle, the $\mathrm{CD}^{-} 5^{-} \mathrm{CD} 56^{+} \mathrm{CD} 34^{-}$ $\mathrm{CD} 140 \mathrm{a}^{+}$and $\mathrm{CD} 45^{-} \mathrm{CD} 56^{+} \mathrm{CD} 34^{+} \mathrm{CD} 140 \mathrm{a}^{+}$cell populations were abundant. Of these two cell populations, only the proportions of $\mathrm{CD} 45^{-} \mathrm{CD} 56^{+} \mathrm{CD} 34^{+} \mathrm{CD} 140 \mathrm{a}^{+}$cells increased $(\mathrm{P} \leq 0.05)$ in pigs housed in poor hygiene compared with good hygiene conditions. For the $\mathrm{CD}^{4} 5^{-} \mathrm{CD} 56^{-}$ $\mathrm{CD}^{-} 4^{-}$cell population, present in low proportion, there was an interaction between hygiene condition and genetic line $(\mathrm{P} \leq 0.05)$ with a decrease in low RFI pigs housed in poor hygiene conditions. In adipose tissue, the two abundant MSC populations were $\mathrm{CD}^{-} 5^{-} \mathrm{CD}^{-} 6^{-} \mathrm{CD} 34^{-}$and

$54 \mathrm{CD}^{-} 5^{-} \mathrm{CD} 56^{+} \mathrm{CD} 34^{-}$. The proportion of $\mathrm{CD}^{-} 5^{-} \mathrm{CD} 56^{-} \mathrm{CD} 34^{-}$cells increased $(\mathrm{P} \leq 0.05)$ whereas the 55 proportion of $\mathrm{CD}^{-} 5^{-} \mathrm{CD} 56^{+} \mathrm{CD} 34^{-}$tended to decrease $(\mathrm{P} \leq 0.1)$ in pigs housed in poor conditions.

56 This study shows that the proportions of some MSC populations were affected by hygiene of

57 housing conditions in a tissue-dependent manner in pigs of both RFI lines. Therefore, these cell

58 populations could be targeted to modulate growth and body composition in growing animals. 


\section{Introduction}

63 During postnatal growth and development, farm animals like pigs are exposed to a diversity of

64 environmental stimuli (Colditz et al., 2016). Stressful situations like transport and housing in

65 poor hygiene conditions can result in immune system hyper-activation. The animal ability to

66 cope with these different challenges will influence the growth of their productive tissues and

67 subsequently their growth efficiency and robustness. Fat animals are generally less efficient in

68 the conversion of feed into meat (Sillence, 2004). Moreover, as excess body fat triggers the

69 production of immune and inflammatory cells, the lean-to-fat ratio in the body may influence the

70 ability to fight against infection, and thus the robustness of animals (Patience, Rossoni-Serão \&

71 Gutiérrez, 2015). Hence, a better control of body composition in growing pigs requires a better

72 understanding of the dynamics and flexibility of muscle and adipose tissue growth when the

73 environment surrounding pigs is modified. The mass of skeletal muscle and adipose tissue is

74 largely determined by the number and size of muscle fibers and adipocytes (Lefaucheur, 2010;

75 Louveau et al., 2016). This increase in cell number results from recruitment of multipotent

76 mesenchymal stromal/stem cells (MSCs) resident in tissues (Dominici et al., 2006). These cells

77 comprise heterogeneous populations of undifferentiated cells able of self-renewal with the

78 capacity to differentiate into cells of the mesenchymal lineage (adipocytes, myocytes or

79 osteocytes for instance). These MSCs have now emerged as important targets to control growth

80 and final body composition in livestock (Johnson, 2013; Dodson et al., 2015).

The identification of MSC populations is based on the use of a combination of cell surface

83 markers and flow-cytometry (Bourin et al., 2013; Relaix et al., 2021). Thus, MSCs are positive

84 for CD105, CD90, CD73 and negative for hematopoietic markers CD11b, CD14, CD34 and

85 CD45. More specifically, both skeletal muscle and adipose tissue cells include resident MSCs

86 that share common cell surface markers. For example, the CD56 marker, also known as a neural

87 cell adhesion molecule (NCAM) and a myogenic marker in muscle (Pisani et al., 2010a;

88 Wilschut et al., 2011; Uezumi et al., 2014), has been also found in MSCs from porcine adipose

89 tissue. Recently, the phenotypic marker CD140a, or platelet derived growth factor receptor alpha

90 (PDGFR $\alpha)$ emerged as an important MSC marker. It has been shown that CD140a ${ }^{+}$cells derived

91 from muscle or adipose tissue have adipogenic potential (Lee \& Granneman, 2012, Uezumi et

92 al., 2010, 2016; Sun, Berry \& Olson, 2017). Finally, CD38, one of the main NAD-degrading 
enzymes in mammalian tissues, has been suggested as a novel marker of committed

94 preadipocytes in mice (Carrière et al., 2017). Other studies have shown that the combination of

95 CD34 and CD56 markers allow the discrimination between myogenic and adipogenic

96 progenitors in human and pig muscle (Pisani et al., 2010a,b; Perruchot et al., 2013). Taken

97 together, these cell surface markers could be used to decipher the functional signatures of muscle

98 and adipose tissue.

100 Thus, despite the well-known relationship between adipose tissue and skeletal muscle throughout 101 life (Crisan et al., 2008; De Carvalho et al., 2019), there is a notable lack of studies investigating 102 deeply these two tissues. In this context, we propose to characterize and compare MSCs 103 populations from adipose and skeletal muscle tissues in response to an environmental challenge 104 in two pig lines divergently selected for feed efficiency (Gilbert et al., 2007). With a genetic 105 selection mainly based on production criteria for more than 50 years, pigs are potentially more 106 susceptible to infectious diseases and have a weaker immune response (Knap \& Doeschl-Wilson, 107 2020). In order to determine if genetic selection has an impact on the immune response of the 108 best performing pigs, a sanitary challenge (good versus poor hygiene of housing conditions) was 109 recently carried out on two lines of pigs divergent for their residual feed intake (RFI), a measure 110 of feed efficiency (Chatelet et al., 2018). It has been shown that this sanitary challenge reduced 111 the growth performance of pigs and stimulated their immune system (Le Floc'h et al., 2014). We 112 hypothesized that hygiene of housing conditions will impact the proportions of hematopoietic 113 and/or MSC cells in subcutaneous adipose tissue (SCAT) and skeletal muscle and that the 114 response may differ between pigs with different RFI. 


\section{Materials \& Methods}

\section{Ethical approval/declaration}

The experiment was performed in the INRAE UE3P experimental facility (Saint-Gilles, France; (doi.org/10.15454/1.5573932732039927E12) in compliance with the ethical standards of the European Community (Directive 2010/63/EU) and was approved by the regional ethical committee (Comité Rennais d'Ethique en matière d'expérimentation animale or CREEA Rennes). The experiment approval number is APAFIS\#494-2015082717314985.

\section{Animals}

For this experiment, a subset of pigs was selected from the period 1 of a larger study previously described by Chatelet et al. (2018). Growing Large-White pigs (males and females) originated from the 8th generation of two lines divergently selected for residual feed intake (RFI), a measure of feed efficiency (Gilbert et al., 2007). Briefly, animals from the high RFI (HRFI) and the low RFI (LRFI) lines were weaned at 4 weeks of age. At 11 weeks $(\approx 25 \mathrm{~kg})$, half of the LRFI and HRFI pigs were then assigned to either a room with good hygiene conditions and the other half to a room with poor hygiene conditions. Good housing conditions included room cleaning, disinfection, and adoption of strict biosecurity precautions. In contrast, poor hygiene conditions consisted of no cleaning nor sanitation of the room after the previous occupation by non-experimental pigs. All pigs were housed in individual pens $(85 \times 265 \mathrm{~cm})$ in concrete floor throughout the experimental period and were fed ad libitum a standard diet formulated to meet or exceed the nutritional requirement of growing pigs $(9.47 \mathrm{MJ}$ of net energy $/ \mathrm{kg}$, starch $44.2 \%$; fat $3.1 \%$; crude protein $15.3 \%$. They had free access to water. After six weeks of challenge and after an overnight fast, animals ( $\mathrm{n}=5-9$ /experimental group) were euthanized by electrical stunning

147 and exsanguination. Immediately after slaughter, samples of subcutaneous dorsal adipose tissue 148 (SCAT) and of longissimus muscle were excised and placed in $37^{\circ} \mathrm{C}$ Krebs-Ringer-bicarbonateHEPES buffer for cell isolation (Perruchot et al., 2013).

\section{Adipose cell isolation}

152 Cells were isolated from a sample of fresh dorsal subcutaneous adipose tissue by collagenase 153 digestion as previously described (De clercq et al., 1997; Perruchot et al., 2013). Briefly, fresh 
adipose tissue was cut into small pieces and dissociated by enzymatic digestion with collagenase II and XI (800 U/mg; Sigma, St. Quentin Fallavier, France) under shaking in a dry bath for 45 $\min$ at $37^{\circ} \mathrm{C}$. Then, a centrifugation at $400 \mathrm{~g}$ for $10 \mathrm{~min}$ was performed to separate floating adipocytes from the pellet of stromal vascular fraction (SVF) cells. After resuspension, SVF cells were successively filtered through a $200-\mu \mathrm{m}$ and $25-\mu \mathrm{m}$ nylon membranes (Dutscher, Brumath, France). After isolation, SVF cells were placed in 90\% Fetal Calf Serum (FCS) and 10\% dimethyl sulfoxide (1-2 million cells per $\mathrm{mL})$ and frozen at $-150{ }^{\circ} \mathrm{C}$.

\section{Muscle cell isolation}

Fresh muscle tissue devoid of visible connective tissue was finely chopped and digested for $3 \mathrm{x}$ 20 min in a $\mathrm{Ca}^{2+}$-free medium containing 0.25\% trypsin (Invitrogen, Cergy-Pontoise, France), $1.5 \mathrm{mg} / \mathrm{mL}$ collagenase II (PAA Laboratoires, Les Mureaux, France), and 0.1\% DNAse (Sigma, St. Quentin Fallavier, France) in a shaking water bath at $37^{\circ} \mathrm{C}$. After centrifugation at $800 \mathrm{~g}$ for 10 min at $4^{\circ} \mathrm{C}$, cell pellet was re-suspended in ice-cold proliferation growth medium (PGM) containing DMEM supplemented with 10\% FCS (Invitrogen), 10\% horse serum (Invitrogen), and Penicillin 6,25 UI/ml -Streptomycin 6,25 $\mu \mathrm{g} / \mathrm{ml}$, (Fisher Scientific, Illkirch, France). Next, cell suspension was successively filtered through a 200- $\mu \mathrm{m}$ and 50- $\mu \mathrm{m}$ Nylon mesh (Dutscher, Brumath, France). After their collection in ice-cold PGM, isolated cells were placed in 90\% Fetal Calf Serum (FCS) and 10\% dimethyl sulfoxide (1-2 million cells per mL) and frozen at $173-150{ }^{\circ} \mathrm{C}$.

\section{Flow cytometry analysis}

176 Individual vials of cryopreserved cells were thawed in a $37^{\circ} \mathrm{C}$ water bath $(2-3 \mathrm{~min})$. After

177 thawing, cells were suspended in $10 \mathrm{~mL}$ of FCS (Sigma). After centrifugation at $500 \mathrm{~g}$ for $5 \mathrm{~min}$

178 at room temperature (RT), cells were suspended in $10 \mathrm{~mL}$ of DPBS (Fisher Scientific, Illkirch, 179 France). Cells were then counted with the TC20 ${ }^{\mathrm{TM}}$ Automated Cell Counter (Bio-Rad, Marnes180 la-Coquette, France). Next, cells were centrifuged at $500 \mathrm{~g}$ for $5 \mathrm{~min}$ at RT and suspended in 10 181 mL of FACS buffer. This FACS buffer contained MACSQuant Running Buffer (Miltenyi Biotec, 182 Paris, France) and 0.5\% of MACS® BSA Stock Solution (Miltenyi Biotec). Cells were 183 dispensed at 50,000 cells for SCAT and 500,000 cells for muscle in each round bottom tube of 5 $\mathrm{mL}$ (Sarstedt, Nümbrecht, Germany). After centrifugation at $500 \mathrm{~g}$ for $5 \mathrm{~min}$ at RT, cells were 


\begin{tabular}{|cccc|}
\hline \multicolumn{1}{c}{ Antigen } & Antibody & Reference & Supplier \\
& & & \\
\hline CD34 & CD34-PE (clone EP373Y) & ab223930 & Abcam \\
Isotype control & IgG-PE (clone EPR25A) & ab209478 & Abcam \\
\hline CD38 & CD38-PE-Vio770 (clone REA 671) & $130-119-159$ & Miltenyi Biotec \\
Isotype control & IgG1-PE-vio770 (REA 293) & $130-113-440$ & Miltenyi Biotec \\
\hline CD45 & CD45-FITC (clone K252.1E4) & MCA1222F & BIO RAD \\
Isotype control & IgG1-FITC (clone MCA928F) & MCA928F & BIO RAD \\
\hline CD56 & CD56-BV421 (clone NCAM16.2) & 562751 & BD Biosciences \\
Isotype control & (BALB/c)-BV421 IgG2b, $\kappa$ & 562748 & BD Biosciences \\
\hline CD140a & CD140a-APC (clone REA 637) & $130-122-942$ & Miltenyi Biotec \\
Isotype control & IgG1-APC (REA 293) & $130-113-434$ & Miltenyi Biotec \\
\hline
\end{tabular}
labeled monoclonal or polyclonal antibodies coupled to different fluorochromes: allophycocyanine (APC), brilliant violet 421 (BV421), fluorescein isothiocyanate (FITC), phycoerythrin (PE), phycoerythrin-vio770 (PE-Vio770) (Table 1). After incubation with antibodies, cells were washed in FACS buffer and centrifuged at $500 \mathrm{~g}$ for $5 \mathrm{~min}$ at $4^{\circ} \mathrm{C}$. Labeled cells were then suspended in $400 \mu \mathrm{L}$ of FACS buffer. Labeled cells were analyzed using a MACSQuant Analyzer 10 flow cytometer (Miltenyi Biotec), which was calibrated daily. A minimum of 50,000 events was acquired per sample for SCAT and 200,000 events for muscle. Flow cytometry analysis were performed with appropriate isotype matching negative and Flow Minus One (FMO) controls. Data were analyzed using the FlowLogic software (Inivai, Mentone, Victoria, Australia).

Table 1: List of antibodies used for flow cytometry analysis. 


\section{Statistical analyzes}

206 Statistical analyzes were performed using the GraphPad Prism software (version 8.4.3 (686), San

207 Diego, CA, USA). The data were subjected to the two-way analysis of variance (ANOVA).

208 Hygiene of housing conditions, RFI line and their interactions were considered as fixed effects.

209 Results are presented as mean \pm standard error of mean (SEM). Differences were considered

210 statistically significant at $\mathrm{P} \leq 0.05$ and were discussed as a trend for $0.05<\mathrm{P}<0.1$. 


\section{Results}

233 Growth performance and body composition of the studied groups

234 Growth performance (Chatelet et al., 2018) and body composition (Sierżant et al., 2019) of pigs

235 have been previously described for a greater number of experimental pigs. Data for the subset of

236 pigs investigated in the current study are shown in Table 2. First, there was no significant

237 interaction between housing conditions and RFI lines for pig performance and their body

238 composition. Final body weights, average daily gain and backfat weight did not differ between

239 the experimental groups $(\mathrm{P}>0.1)$. Interestingly, irrespective of housing conditions, the relative

240 loin weight was lower in HRFI pigs than in LRFI pigs $(\mathrm{P}=0.005)$. Finally, irrespective of the

241 RFI line, the loin/backfat ratio was higher $(\mathrm{P}=0.045)$ in pigs raised in poor conditions than in

242 pigs raised in good conditions.

\begin{tabular}{|c|c|c|c|c|ccc|}
\cline { 2 - 8 } \multicolumn{1}{c|}{} & \multicolumn{2}{c|}{ Good } & \multicolumn{2}{c|}{ Poor } & \multicolumn{3}{c|}{ P-values } \\
\cline { 2 - 8 } & LRFI & HRFI & LRFI & HRFI & Hyg & Line $\begin{array}{c}\text { Hyg x } \\
\text { Line }\end{array}$ \\
\hline $\begin{array}{c}\text { Initial body } \\
\text { weight (kg) }\end{array}$ & $27.8 \pm 0.7$ & $25.7 \pm 1.7$ & $28.2 \pm 0.7$ & $25 \pm 1.4$ & 0.402 & 0.495 & 0.289 \\
\hline $\begin{array}{c}\text { Final body } \\
\text { weight (kg) }\end{array}$ & $54.6 \pm 2.6$ & $51.1 \pm 1.9$ & $54.0 \pm 3.4$ & $49.8 \pm 3.3$ & 0.783 & 0.174 & 0.958 \\
\hline $\begin{array}{c}\text { Average } \\
\text { daily gain } \\
\text { (g/day) }\end{array}$ & $626 \pm 67$ & $590 \pm 59$ & $603 \pm 84$ & $564 \pm 48$ & 0.750 & 0.614 & 0.919 \\
\hline $\begin{array}{c}\text { Relative } \\
\text { loin weight } \\
\text { (\%) }\end{array}$ & $27.6 \pm 0.3$ & $27.0 \pm 0.3$ & $28.4 \pm 0.2$ & $27.2 \pm 0.5$ & 0.137 & $\mathbf{0 . 0 0 5}$ & 0.274 \\
\hline $\begin{array}{c}\text { Relative } \\
\text { backfat } \\
\text { weight (\%) }\end{array}$ & $4.9 \pm 0.2$ & $5.0 \pm 0.1$ & $4.6 \pm 0.3$ & $4.6 \pm 0.3$ & 0.125 & 0.903 & 0.962 \\
\hline $\begin{array}{c}\text { Loin/backfat } \\
\text { ratio }\end{array}$ & $5.6 \pm 0.2$ & $5.5 \pm 0.2$ & $6.5 \pm 0.5$ & $6.0 \pm 0.3$ & $\mathbf{0 . 0 4 5}$ & 0.322 & 0.638 \\
\hline
\end{tabular}

243

244

245

246

247

248

Table 2: Growth performance of low (LRFI) and high (HRFI) residual feed intake pigs housed in good or poor hygiene conditions for six weeks.

Values are means \pm SEM ( $\mathrm{n}=5-9$ pigs/experimental group). Boldface highlights significant differences $(\mathrm{P} \leq 0.05)$. ${ }^{1}$ Probability values for the effect of hygiene conditions (Hyg), genetic lines (Line), and their interaction. 


\section{Description of the phenotyping strategy}

251 To identify the cell populations specific and common to SCAT and muscle, we focused our 252 analysis on a panel of five cell surface markers: CD45, CD34, CD38, CD56 and CD140a (Figure 253 1).

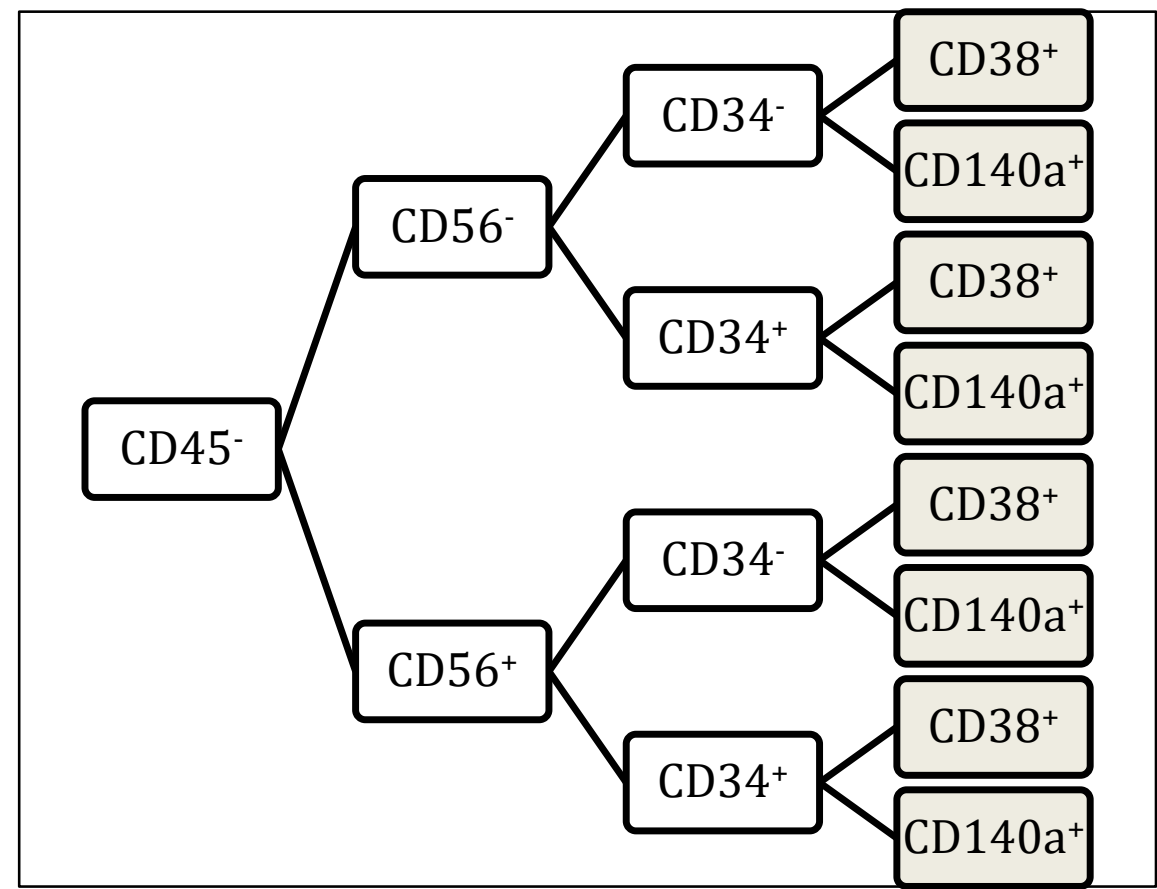

Figure 1: Diagram of the strategy used for cell immunophenotyping by flow cytometry.

Adult stem cells were isolated from adipose tissue and skeletal of growing pigs with low and high residual feed intake and housed in good or poor hygiene conditions for six weeks. A common analytical strategy was used for both tissues. However, adipose tissue was phenotyped at the level of triple lineage because of its low quantities of $\mathrm{CD}^{-} 5^{-} \mathrm{CD} 56^{-} \mathrm{CD} 34^{+}$and $\mathrm{CD}^{-}$ $\mathrm{CD} 56^{+} \mathrm{CD} 34^{+}$cells (white squares).

First, gating was performed on living cells that were negative for the CD45 in order to remove hematopoietic cells positive for the CD45 marker. Next, we analyzed the following combinations in SCAT and muscle: CD45-CD34+, CD45-CD $38^{+}, \mathrm{CD}^{-} 5^{-} \mathrm{CD} 56^{-}, \mathrm{CD}^{-} 5^{-} \mathrm{CD} 56^{+}, \mathrm{CD}^{\circ} 5^{-} \mathrm{CD} 140 \mathrm{a}^{+}$. Then, we performed a deeper phenotyping for cell populations predominant in both SCAT and muscle, respectively $\mathrm{CD}^{-} 5^{-} \mathrm{CD} 56^{-}$and $\mathrm{CD}^{-} 5^{-} \mathrm{CD}^{\circ} 6^{+}$(Figures 2 and 3). Based on the literature, we evaluated within these two cell populations, the expression of the CD34 marker as named:

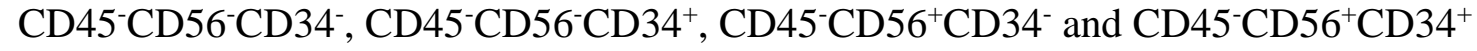


269 populations. Given the low proportion $(<0.5 \%)$ of some cell populations in SCAT, we only analyzed the expression of the CD38 and CD140a cell surface markers in muscle in order to

271 highlight the proportion of the following populations: $\mathrm{CD}^{-} 5^{-} \mathrm{CD} 56^{-} \mathrm{CD} 34^{-} \mathrm{CD} 38^{+}, \mathrm{CD}^{-} 5^{-} \mathrm{CD}^{-}$

$272 \mathrm{CD}^{-} 4^{-\mathrm{CD}} 140 \mathrm{a}^{+}, \mathrm{CD} 45^{-} \mathrm{CD} 56^{-} \mathrm{CD} 34^{+} \mathrm{CD} 38^{+}, \mathrm{CD}^{-} 5^{-\mathrm{CD}} 56^{-} \mathrm{CD} 34^{+} \mathrm{CD} 140 \mathrm{a}^{+}, \mathrm{CD}^{-} 5^{-} \mathrm{CD} 56^{+} \mathrm{CD} 34^{-}$

$273 \mathrm{CD}^{2} 8^{+}, \mathrm{CD} 45^{-} \mathrm{CD} 56^{+} \mathrm{CD} 34^{-} \mathrm{CD} 140 \mathrm{a}^{+}, \mathrm{CD} 45^{-} \mathrm{CD}^{-} 6^{+} \mathrm{CD} 34^{+} \mathrm{CD} 38^{+}$and $\mathrm{CD} 45^{-}$

$274 \mathrm{CD}^{+} 6^{+} \mathrm{CD} 34^{+} \mathrm{CD} 140 \mathrm{a}^{+}$. Altogether, this gating strategy allowed us to highlight specific and 275 common cell populations in both at SCAT and muscle.

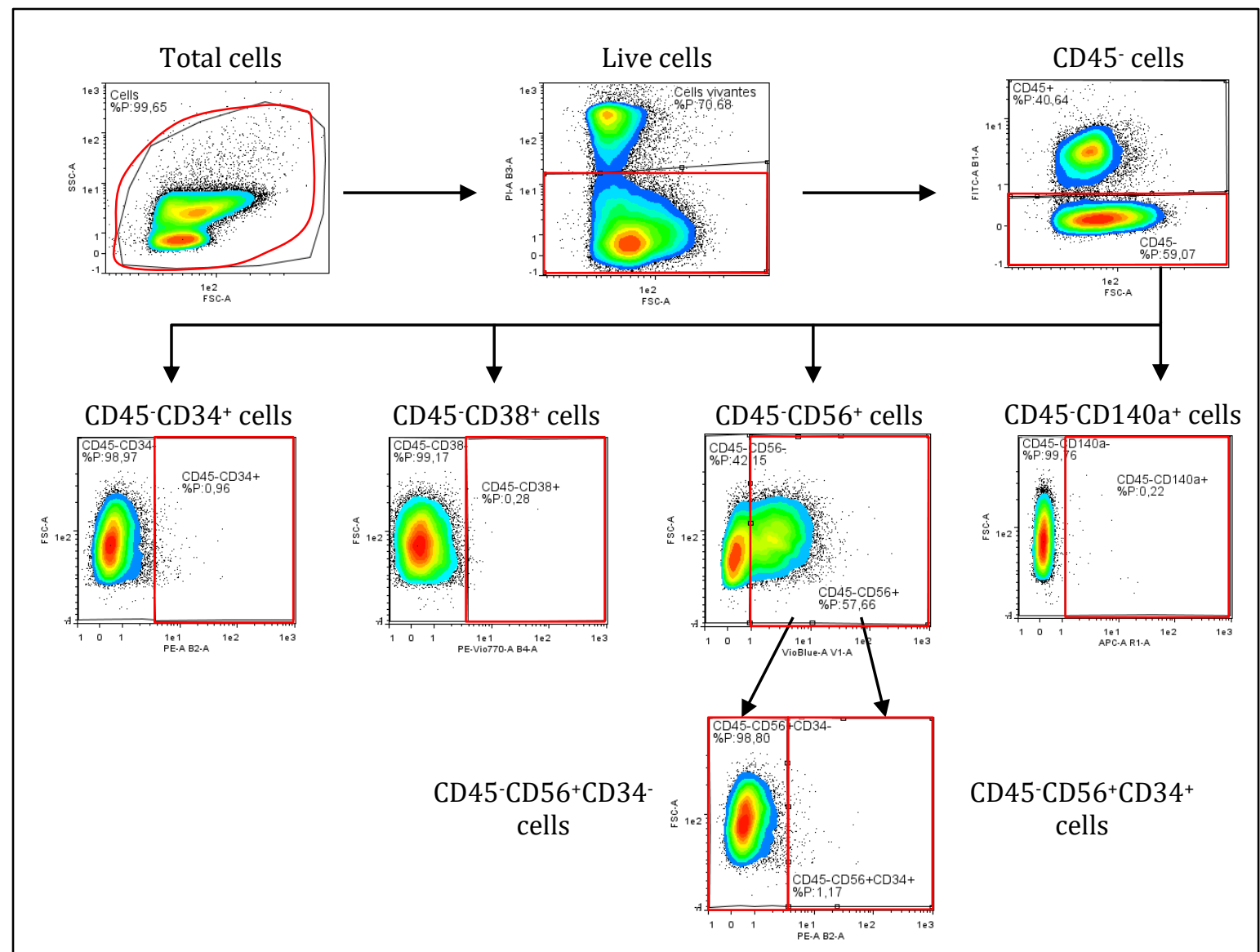

Figure 2: Representative flow cytometry plots illustrating the immunophenotyping strategy used for adult stem cells isolated from adipose subcutaneous tissue of growing pigs. The captions correspond to the cell populations highlighted in red. In addition, the red boxes delimit the positivity threshold of studied cell populations established according to the appropriate isotype and Fluorescence Minus One controls. 


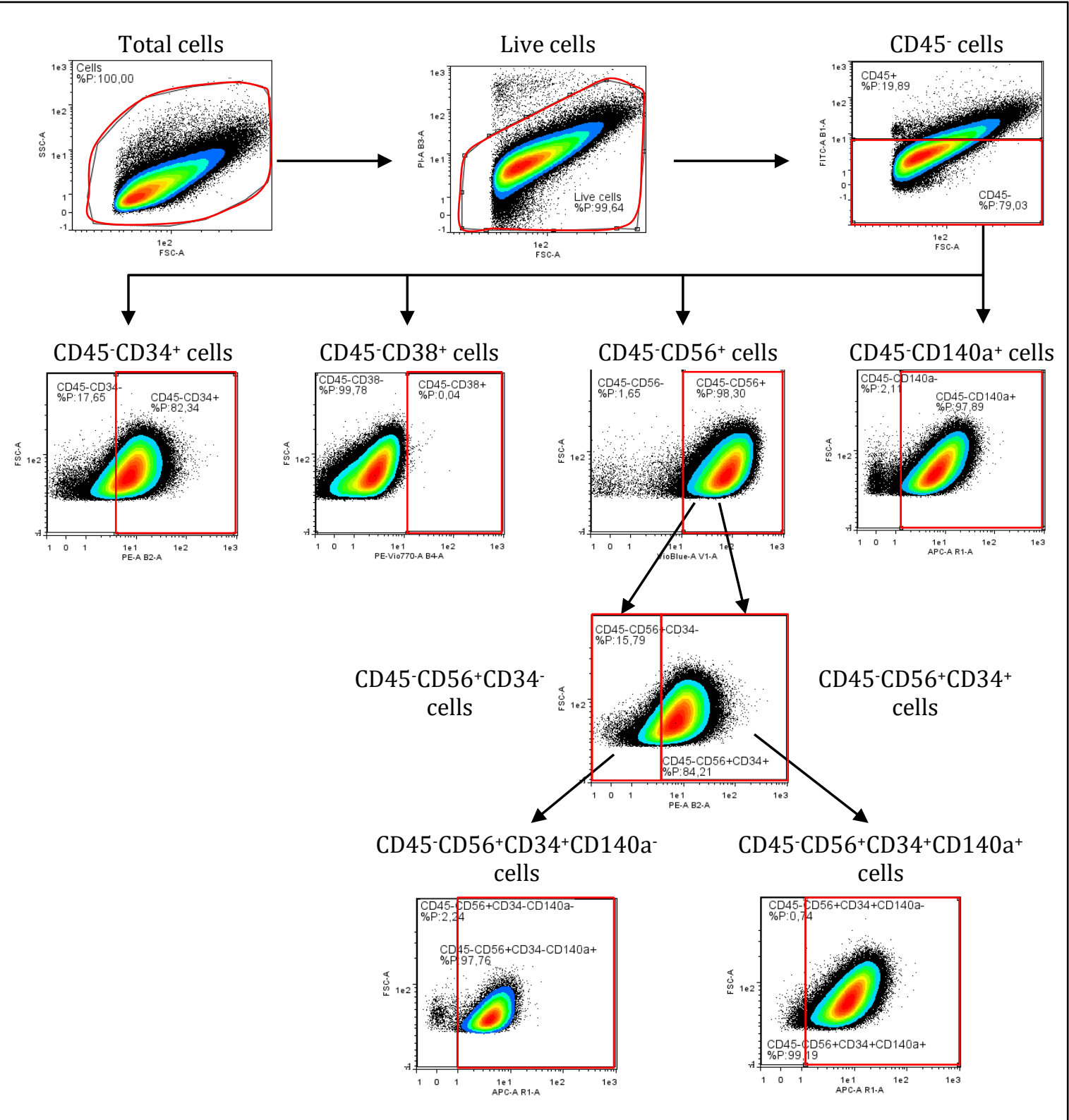

Figure 3: Representative flow cytometry plots illustrating the immunophenotyping strategy used for adult stem cells isolated from skeletal muscle tissue of growing pigs. The captions correspond to the cell populations highlighted in red. In addition, the red boxes delimit the positivity threshold of studied cell populations established according to the appropriate isotype and Fluorescence Minus One controls. 


\section{Analysis of cell populations identified in subcutaneous adipose tissue}

296 There was a significant proportion of $\mathrm{CD}^{+} 5^{+}$cells $(23.1 \%)$ in SCAT with no difference between

297 the four experimental groups (Table 3). We next analyzed the occurrence of co-staining for the

298 four cell surface markers CD56, CD34, CD38 and CD140a in order to further delineate the

299 different populations within CD45 cells dissociated from SCAT. With triple staining, the

300 proportions of the $\mathrm{CD}^{-} 5^{-} \mathrm{CD}^{-} 6^{-} \mathrm{CD} 34^{-}$population was higher $(+11.7 \%, \mathrm{P}=0.034)$ in poor than in

301 good hygiene of housing conditions whatever the RFI line (Figure 4A) whereas the proportion of

302 the $\mathrm{CD}^{-} 5^{-} \mathrm{CD} 56^{+} \mathrm{CD} 34^{-}$population tended to decrease $(-17.2 \%, \mathrm{P}=0.099)$ in poor hygiene

303 conditions compared with good conditions (Figure 4C). Of note, the other cell populations with

304 double or triple staining, such as $\mathrm{CD} 45^{-} \mathrm{CD} 56^{+} \mathrm{CD} 34^{+}$cells (Figure $4 \mathrm{E}$ ) were present in very low

305 proportions $(<1 \%)$ in SCAT (Table 3).

306

307

308

309

310

311

312

313

314

315

316

317

318 
Table 3: Percentage of adult stem cell populations in subcutaneous adipose tissue of low (LRFI) and high (HRFI) residual feed intake pigs housed in good or poor hygiene conditions for six weeks.

\begin{tabular}{|c|c|c|c|c|c|c|c|}
\hline \multirow[b]{2}{*}{$\begin{array}{c}\text { Cell } \\
\text { populations }\end{array}$} & \multicolumn{2}{|c|}{ Good } & \multicolumn{2}{|c|}{ Poor } & \multicolumn{3}{|c|}{$P$-values ${ }^{1}$} \\
\hline & LRFI & HRFI & LRFI & HRFI & Hyg & Line & $\begin{array}{c}\text { Hyg x } \\
\text { Line }\end{array}$ \\
\hline $\mathrm{CD}^{+} 5^{+}$ & $\begin{array}{r}18.2 \\
\pm 7.1\end{array}$ & $\begin{array}{r}22.7 \\
\pm 7.1\end{array}$ & $\begin{array}{r}26.7 \\
\pm 5.1\end{array}$ & $\begin{array}{l}24.1 \\
\pm 5.4\end{array}$ & 0.434 & 0.880 & 0.571 \\
\hline CD45- & $\begin{array}{l}81.5 \\
\pm 7.1\end{array}$ & $\begin{array}{r}77.0 \\
\pm 7.1\end{array}$ & $\begin{array}{r}72.7 \\
\pm 5.2\end{array}$ & $\begin{array}{r}75.7 \\
\pm 5.4\end{array}$ & 0.429 & 0.905 & 0.558 \\
\hline $\mathrm{CD}^{-\mathrm{CD}^{-}}{ }^{+}{ }^{+}$ & $\begin{array}{c}0.5 \\
\pm 0.2\end{array}$ & $\begin{array}{c}0.3 \\
\pm 0.1\end{array}$ & $\begin{array}{c}0.4 \\
\pm 0.1\end{array}$ & $\begin{array}{c}0.6 \\
\pm 0.1\end{array}$ & 0.530 & 0.844 & 0.071 \\
\hline $\mathrm{CD}^{4}{ }^{-\mathrm{CD}^{-}}{ }^{+}$ & $\begin{array}{l}0.3 \\
\pm 0.1\end{array}$ & $\begin{array}{c}0.2 \\
\pm 0.1\end{array}$ & $\begin{array}{c}0.4 \\
\pm 0.1\end{array}$ & $\begin{array}{c}0.5 \\
\pm 0.1\end{array}$ & 0.082 & 0.779 & 0.212 \\
\hline $\mathrm{CD}^{-}$-CD140a $^{+}$ & $\begin{array}{c}0.5 \\
\pm 0.1\end{array}$ & $\begin{array}{c}0.1 \\
\pm 0.02\end{array}$ & $\begin{array}{c}0.3 \\
\pm 0.1\end{array}$ & $\begin{array}{l}0.3 \\
\pm 0.1\end{array}$ & 0.607 & 0.059 & 0.036 \\
\hline $\mathrm{CD}^{-\mathrm{CD}^{-} \mathrm{CD}}{ }^{-}$ & $\begin{array}{r}27.4 \\
\pm 6.0\end{array}$ & $\begin{array}{r}29.5 \\
\pm 5.2\end{array}$ & $\begin{array}{r}42.4 \\
\pm 3.7\end{array}$ & $\begin{array}{l}36.8 \\
\pm 5.1\end{array}$ & 0.035 & 0.724 & 0.448 \\
\hline $\mathrm{CD}^{-}{ }^{-\mathrm{CD} 56^{-} \mathrm{CD} 34^{-}}$ & $\begin{array}{l}26.8 \\
\pm 6.0\end{array}$ & $\begin{array}{r}29.2 \\
\pm 5.2\end{array}$ & $\begin{array}{r}41.9 \\
\pm 3.7\end{array}$ & $\begin{array}{r}36.4 \\
\pm 5.0\end{array}$ & 0.034 & 0.757 & 0.442 \\
\hline $\mathrm{CD}^{-}{ }^{-}{ }^{-} \mathrm{CD} 56^{-} \mathrm{CD} 34^{+}$ & $\begin{array}{c}0.6 \\
\pm 0.2\end{array}$ & $\begin{array}{c}0.2 \\
\pm 0.04\end{array}$ & $\begin{array}{c}0.5 \\
\pm 0.2\end{array}$ & $\begin{array}{c}0.3 \\
\pm 0.1\end{array}$ & 0.746 & 0.106 & 0.591 \\
\hline $\mathrm{CD}^{-\mathrm{CD}^{-}}{ }^{+}{ }^{+}$ & $\begin{array}{l}53.9 \\
\pm 12.2\end{array}$ & $\begin{array}{r}47.3 \\
\pm 9.9\end{array}$ & $\begin{array}{l}30.1 \\
\pm 6.2\end{array}$ & $\begin{array}{c}38.6 \\
\pm 10.0\end{array}$ & 0.101 & 0.920 & 0.437 \\
\hline $\mathrm{CD}^{-}{ }^{-} \mathrm{CD56}^{+} \mathrm{CD}^{-} 4^{-}$ & $\begin{array}{c}53.7 \\
\pm 12.3\end{array}$ & $\begin{array}{c}47.1 \\
\pm 10.0\end{array}$ & $\begin{array}{l}29.8 \\
\pm 6.2\end{array}$ & $\begin{array}{c}38.3 \\
\pm 10.0\end{array}$ & 0.099 & 0.922 & 0.439 \\
\hline $\mathrm{CD}^{-}{ }^{-\mathrm{CD}^{-}}{ }^{+} \mathrm{CD}^{-} 4^{+}$ & $\begin{array}{c}0.2 \\
\pm 0.1\end{array}$ & $\begin{array}{c}0.2 \\
\pm 0.1\end{array}$ & $\begin{array}{c}0.2 \\
\pm 0.1\end{array}$ & $\begin{array}{c}0.3 \\
\pm 0.1\end{array}$ & 0.230 & 0.653 & 0.693 \\
\hline
\end{tabular}

324 Values are means \pm SEM ( $\mathrm{n}=6-9$ pigs/experimental group). Boldface highlights significant 325 differences $(\mathrm{P} \leq 0.05)$ and italicized characters show a trend $(0.05<\mathrm{P}<0.10)$.

$326{ }^{1}$ Probability values for the effect of hygiene conditions (Hyg), genetic lines (Line), and their 327 interaction. 


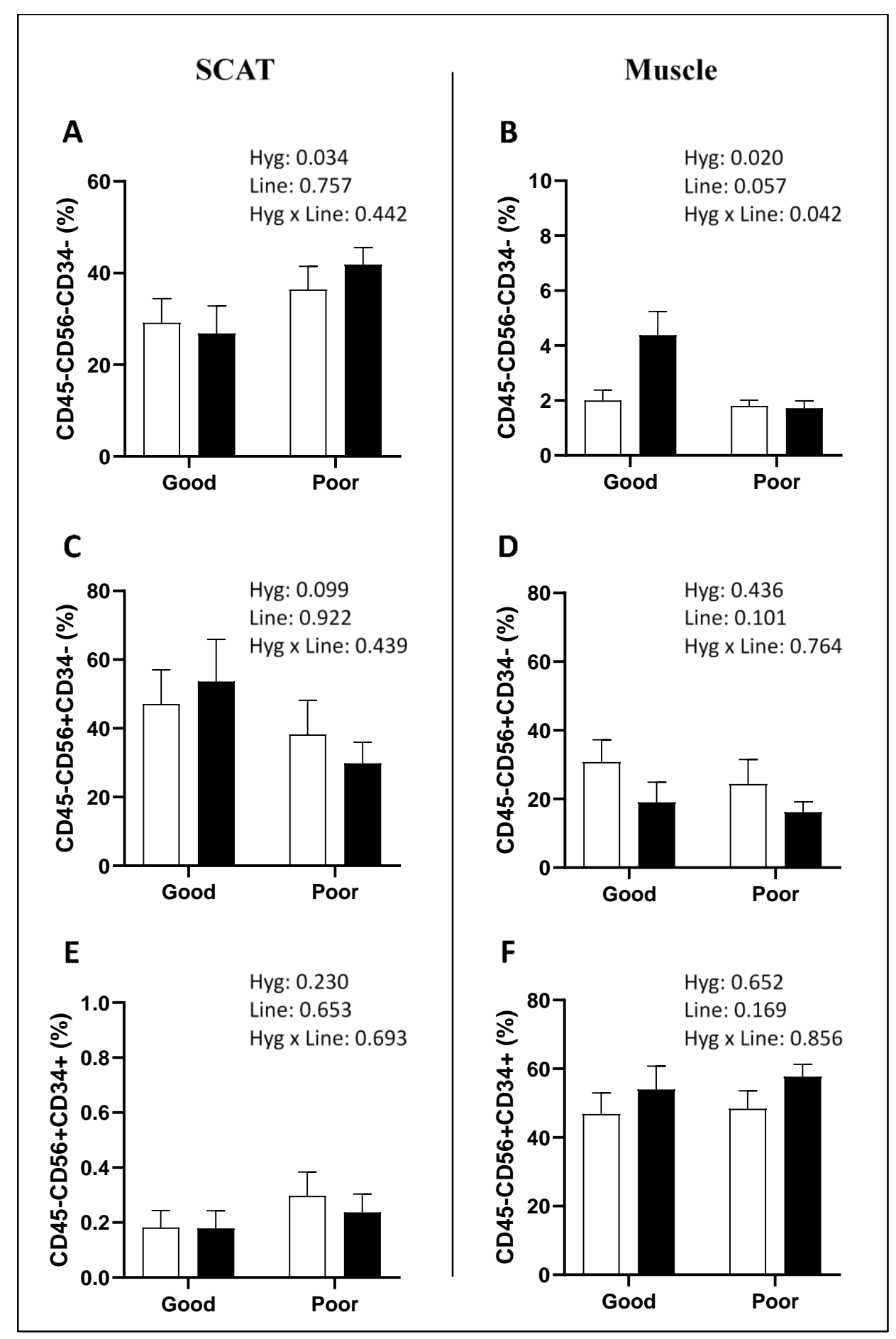

Figure 4: Percentage of adult stem cell populations in subcutaneous adipose tissue (SCAT) as means $\pm \operatorname{SEM}(n=5-9 /$ experimental group $)$. 


\section{Analysis of cell populations identified in skeletal muscle}

336 The proportion of $\mathrm{CD}^{4} 5^{+}$cells in muscle was in the range of 20-23\% (Table 4) and increased $337 \quad(\mathrm{P}=0.020)$ in pigs housed in poor conditions compared with pigs housed in good conditions for 338 both RFI lines. Next, we analyzed the expression of CD34, CD38, CD140a and CD56 within the $339 \mathrm{CD}^{2}$ - cell population (Figures 1 and 3). Despite their high proportions (>50\%) in muscle, the $340 \mathrm{CD}^{2} 5^{-} \mathrm{CD} 34^{+}$and $\mathrm{CD} 45^{-} \mathrm{CD} 140 \mathrm{a}^{+}$cell populations did not differ significantly between the four 341 groups. Furthermore, there was an interaction for the $\mathrm{CD} 45^{\circ} \mathrm{CD} 56^{-}$cell population $(\mathrm{P}=0.011)$.

342 Interestingly, within this $\mathrm{CD} 45^{-} \mathrm{CD} 56^{-}$cell population, we analyzed the expressions of CD34 and $343 \mathrm{CD} 140$ a. We also observed a significant interaction for the $\mathrm{CD}^{-} 5^{-} \mathrm{CD} 56^{-} \mathrm{CD} 34^{-}$cell population $(\mathrm{P}$ $344=0.042$ ) (Figure $4 \mathrm{~B}$ ). For the $\mathrm{CD}^{-} 5^{-} \mathrm{CD} 56^{-} \mathrm{CD} 34^{-} \mathrm{CD} 140 \mathrm{a}^{+}$cells, their proportion tended to 345 decrease $(\mathrm{P}=0.072)$ in poor compared with good hygiene conditions. Moreover, within the $346 \mathrm{CD}^{-} 5^{-} \mathrm{CD} 56^{+}$cell population, the proportion of $\mathrm{CD} 45^{-} \mathrm{CD} 56^{+} \mathrm{CD} 34^{-}$cells tended to be higher in 347 HRFI pigs $(+10 \%, \mathrm{P}=0.101)$ than in LRFI pigs (Figure 4D). Concerning the CD45-

$348 \mathrm{CD}^{+} 6^{+} \mathrm{CD} 34^{+}$cells, their proportions do not vary whatever the genetic line or the housing 349 conditions (Figure 4F). Finally, by adding the CD140a marker in the analysis, we highlighted 350 that, irrespective of the genetic line, the $\mathrm{CD} 45^{-} \mathrm{CD} 56^{+} \mathrm{CD} 34^{+} \mathrm{CD} 140 \mathrm{a}^{+}$cells increased $(+11.3 \%)$ 351 in poor conditions $(\mathrm{P}=0.052)$ compared with good conditions (Table 4$)$. 
Table 4: Percentage of cell populations in muscle of low (LRFI) and high (HRFI) residual

feed intake pigs housed in good or poor hygiene conditions for six weeks.

\begin{tabular}{|c|c|c|c|c|c|c|c|}
\hline \multirow[b]{2}{*}{ Cell populations } & \multicolumn{2}{|c|}{ Good } & \multicolumn{2}{|c|}{ Poor } & \multicolumn{3}{|c|}{ P-values ${ }^{1}$} \\
\hline & LRFI & HRFI & LRFI & HRFI & Hyg & Line & $\begin{array}{l}\text { Hyg } x \\
\text { Line }\end{array}$ \\
\hline $\mathrm{CD45}^{+}$ & $\begin{array}{l}20.1 \\
\pm 1.5\end{array}$ & $\begin{array}{r}18.6 \\
\pm 1.4\end{array}$ & $\begin{array}{l}23.0 \\
\pm 0.9\end{array}$ & $\begin{array}{l}23.1 \\
\pm 1.9\end{array}$ & 0.020 & 0.620 & 0.560 \\
\hline $\mathrm{CD45}^{-}$ & $\begin{array}{r}79.0 \\
\pm 1.5\end{array}$ & $\begin{array}{l}80.6 \\
\pm 1.4\end{array}$ & $\begin{array}{r}76.4 \\
\pm 1.0\end{array}$ & $\begin{array}{l}76.1 \\
\pm 2.1\end{array}$ & $\mathbf{0 . 0 3 0}$ & 0.678 & 0.552 \\
\hline $\mathrm{CD}^{-\mathrm{CD}^{-}}{ }^{+}$ & $\begin{array}{r}53.3 \\
\pm 7.3\end{array}$ & $\begin{array}{r}47.9 \\
\pm 5.8\end{array}$ & $\begin{array}{r}58.2 \\
\pm 3.7\end{array}$ & $\begin{array}{l}49.5 \\
\pm 4.6\end{array}$ & 0.583 & 0.242 & 0.790 \\
\hline $\mathrm{CD}^{-\mathrm{CD}^{-}}{ }^{+}$ & $\begin{array}{c}0.1 \\
\pm 0.02\end{array}$ & $\begin{array}{c}0.1 \\
\pm 0.02\end{array}$ & $\begin{array}{c}0.1 \\
\pm 0.03\end{array}$ & $\begin{array}{c}0.3 \\
\pm 0.1\end{array}$ & 0.121 & 0.447 & 0.091 \\
\hline $\mathrm{CD}^{-} \mathrm{CD}^{-140 \mathbf{a}^{+}}$ & $\begin{array}{l}55.4 \\
\pm 9.7\end{array}$ & $\begin{array}{l}67.2 \\
\pm 6.4\end{array}$ & $\begin{array}{l}69.1 \\
\pm 3.5\end{array}$ & $\begin{array}{r}67.2 \\
\pm 0.8 \\
\end{array}$ & 0.327 & 0.478 & 0.327 \\
\hline $\mathrm{CD}^{4} 5^{-} \mathrm{CD}^{-} 6^{-}$ & $\begin{array}{c}5.6 \\
\pm 0.9\end{array}$ & $\begin{array}{c}2.6 \\
\pm 0.5\end{array}$ & $\begin{array}{c}2.3 \\
\pm 0.3\end{array}$ & $\begin{array}{c}2.8 \\
\pm 0.5\end{array}$ & 0.024 & 0.073 & 0.011 \\
\hline CD45'CD56-CD34- & $\begin{array}{c}4.4 \\
\pm 0.9\end{array}$ & $\begin{array}{c}2.0 \\
\pm 0.4\end{array}$ & $\begin{array}{c}1.7 \\
\pm 0.3\end{array}$ & $\begin{array}{c}1.8 \\
\pm 0.2\end{array}$ & 0.020 & 0.057 & 0.042 \\
\hline 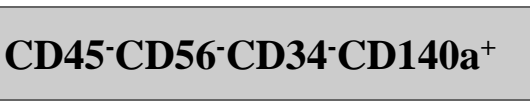 & $\begin{array}{c}1.8 \\
\pm 0.7 \\
\end{array}$ & $\begin{array}{c}1.0 \\
\pm 0.3\end{array}$ & $\begin{array}{c}0.5 \\
\pm 0.1\end{array}$ & $\begin{array}{c}0.5 \\
\pm 0.2\end{array}$ & 0.072 & 0.362 & 0.351 \\
\hline $\mathrm{CD}^{-\mathrm{CD}^{-} \mathrm{CD}}{ }^{-} \mathrm{CD}^{-} 4^{+}$ & $\begin{array}{c}1.2 \\
\pm 0.5\end{array}$ & $\begin{array}{c}0.6 \\
\pm 0.2\end{array}$ & $\begin{array}{c}0.5 \\
\pm 0.1\end{array}$ & $\begin{array}{c}1.0 \\
\pm 0.4\end{array}$ & 0.735 & 0.855 & 0.115 \\
\hline 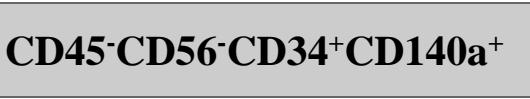 & $\begin{array}{c}0.6 \\
\pm 0.4\end{array}$ & $\begin{array}{c}0.3 \\
\pm 0.2\end{array}$ & $\begin{array}{c}0.2 \\
\pm 0.04\end{array}$ & $\begin{array}{c}0.7 \\
\pm 0.4\end{array}$ & 0.943 & 0.904 & 0.210 \\
\hline $\mathrm{CD}^{4} \mathrm{C}^{-\mathrm{CD}^{-}}{ }^{+}$ & $\begin{array}{r}73.3 \\
\pm 1.4\end{array}$ & $\begin{array}{r}77.9 \\
\pm 1.5\end{array}$ & $\begin{array}{c}74.1 \\
\pm 1.1\end{array}$ & $\begin{array}{r}73.2 \\
\pm 2.4\end{array}$ & 0.224 & 0.245 & 0.099 \\
\hline 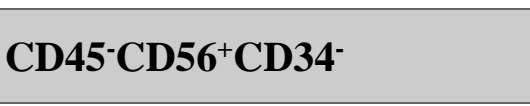 & $\begin{array}{r}19.0 \\
\pm 5.9\end{array}$ & $\begin{array}{r}30.8 \\
\pm 6.5\end{array}$ & $\begin{array}{r}16.2 \\
\pm 3.0\end{array}$ & $\begin{array}{r}24.4 \\
\pm 7.1 \\
\end{array}$ & 0.436 & 0.101 & 0.764 \\
\hline 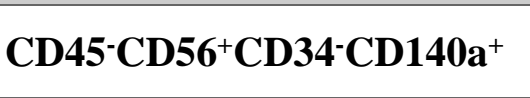 & $\begin{array}{r}17.9 \\
\pm 5.9\end{array}$ & $\begin{array}{r}29.3 \\
\pm 6.4\end{array}$ & $\begin{array}{r}15.6 \\
\pm 2.9\end{array}$ & $\begin{array}{l}23.6 \\
\pm 7.0\end{array}$ & 0.499 & 0.108 & 0.771 \\
\hline $\mathrm{CD}^{-\mathrm{CD}^{-} 6^{+} \mathrm{CD}^{-} 4^{+}}$ & $\begin{array}{r}54.0 \\
\pm 6.8\end{array}$ & $\begin{array}{r}46.8 \\
\pm 6.1\end{array}$ & $\begin{array}{r}57.7 \\
\pm 3.6\end{array}$ & $\begin{array}{r}48.4 \\
\pm 5.2\end{array}$ & 0.652 & 0.169 & 0.856 \\
\hline $\mathrm{CD}^{-} \mathrm{CD56}^{+} \mathrm{CD}^{-}{ }^{+} \mathrm{CD} 140 \mathrm{a}^{+}$ & $\begin{array}{r}36.3 \\
\pm 5.5\end{array}$ & $\begin{array}{l}37.7 \\
\pm 5.4\end{array}$ & $\begin{array}{l}52.7 \\
\pm 3.3\end{array}$ & $\begin{array}{r}43.0 \\
\pm 6.2\end{array}$ & 0.052 & 0.433 & 0.298 \\
\hline
\end{tabular}

358 Values are means \pm SEM ( $\mathrm{n}=5-7$ pigs/experimental group). Boldface highlights significant 359 differences $(\mathrm{P} \leq 0.05)$ and italicized character shows a trend $(0.05<\mathrm{P}<0.10)$. ${ }^{1}$ Probability 360 values for the effect of hygiene conditions (Hyg), genetic lines (Line), and their interaction. The 361 proportions of $\mathrm{CD}^{2} 5^{-\mathrm{CD}} 56^{-\mathrm{CD}} 34^{-\mathrm{CD}} 38^{+}, \mathrm{CD}^{-} 5^{-\mathrm{CD}} 56^{-} \mathrm{CD} 34^{+} \mathrm{CD} 38^{+}, \mathrm{CD}^{-} 5^{-} \mathrm{CD}^{-} 6^{+} \mathrm{CD} 34^{-}$ $\mathrm{CD} 38^{+}$and $\mathrm{CD} 45^{-\mathrm{CD}} 56^{+} \mathrm{CD} 34^{+} \mathrm{CD} 38^{+}$populations were below $0.2 \%$. 


\section{Discussion}

364 The current study was conducted to determine whether the exposure of growing HRFI and LRFI pigs to poor hygiene of housing conditions impact the proportions of adult stem cell populations resident in muscle and adipose tissue, two tissues of importance for body composition and meat quality traits. Whatever the species considered, the characterization of adult stem cells in muscle and adipose tissue is fairly recent and is conventionally carried out using flow cytometry which is based on the use of antibodies directed against cell surface proteins (Bourin et al., 2013; Relaix et al., 2021). For the current cell immunophenotyping, we have used five well-known cell surface markers (CD45, CD56, CD34, CD38 and CD140a) to identify specific and common $\mathrm{CD}^{4} 5^{-}$stem cell populations in both tissues. Moreover, we analyzed for the first time CD45 ${ }^{+}$ cells, a population of hematopoietic cells (Han et al., 2021) known to be increased after injury in muscle (Wosczyna et al., 2019). Our major finding is that the proportions of several cell populations were affected by hygiene of housing conditions in a tissue-dependent manner in pigs of both RFI lines.

The lower growth performance of pigs housed in poor hygiene conditions compared with pigs housed in good hygiene conditions described with a greater number of animals than in the current subset of animals (Chatelet et al., 2018) and the increase in their loin/backfat ratio was associated with changes in the relative proportions of some cell populations in adipose tissue and skeletal muscle. Even though health and growth performance of the most feed efficient LRFI pigs was less impaired by poor hygiene conditions (Chatelet et al., 2018), our findings at the cellular levels do not support a significant relationship between MSC and the better coping ability of LRFI compared with HRFI pigs. In the current study, there was only a significant interaction for the $\mathrm{CD} 45^{-} \mathrm{CD} 56^{-} \mathrm{CD} 34^{-}$population in muscle, a relatively small population. For the other cell populations, there was no significant difference between the two lines. This differs slightly from a previous study showing some differences in some cell populations between the two RFI lines (Perruchot et al., 2020).

The current study clearly shows the presence of a relative high proportion of $\mathrm{CD}^{4} 5^{+}$cells suggesting the presence of hematopoietic cells in both muscle and adipose tissue as shown in 393 previous studies (Cousin et al., 2016; Wosczyna et al., 2019). Our study also indicates that the 
proportion of $\mathrm{CD} 45^{+}$cells in muscle increased with the exposure of pigs to poor hygiene of

395

396

397

398

399

400

401

402

403

404

405

406

407

408

409

410

411

412

413

414

415

416

417

418

419

420

421

422

423

424

housing conditions. This increase may be associated with the inflammation induced by the poor hygiene of housing conditions. The stimulation of the immune system of pigs housed in these conditions was assessed by an increase in plasma haptoglobin concentrations, an acute phase protein (APP), and in white blood cell and granulocyte counts three weeks after the beginning of the challenge (Chatelet et al., 2018). The origin of this increase in $\mathrm{CD}^{4} 5^{+}$cells remains unknown. It could result from an increase in $\mathrm{CD} 45^{+}$resident cells in skeletal muscle.

Alternatively, it could come from other tissues as reported for MSCs in a recent review (Girousse et al., 2021). A study based on the investigation of MSCs from adipose tissue and peripheral blood of Iberian pigs supports an in vitro migration ability of these cells (Calle et al., 2018). Resident MSCs could circulate toward distant inflamed tissues to allow their repair/regeneration. Hence, the observed increase in $\mathrm{CD}_{4} 5^{+}$cells may be associated with changes in local secretory environment and may affect properties of other muscle cells and affect subsequent growth.

As described previously (Bourin et al., 2013; Girousse et al., 2021; Relaix et al., 2021) including in our previous work (Perruchot et al., 2013, 2020), there was a diversity of adult stem cell populations in skeletal muscle and adipose tissue of the different groups of animals. We confirmed that $\mathrm{CD} 45^{-} \mathrm{CD} 56^{+}$cells are predominant in both muscle and adipose tissue as observed before (Perruchot et al., 2013). In porcine muscle, these cells are mainly myogenic (Perruchot et al., 2013). In human and pig, $\mathrm{CD} 45^{-} \mathrm{CD} 56^{+} \mathrm{CD} 34^{-}$were identified as satellite cells (Wilschut et al., 2008; Pisani et al., 2010b; Lewis et al., 2014). In adipose tissue, the presence of CD45-CD56 ${ }^{+}$ is much less documented. We further highlighted a higher cell diversity in muscle than in adipose tissue. There was especially a high proportion of $\mathrm{CD} 34^{+}$and $\mathrm{CD} 140 \mathrm{a}^{+}$cells within the CD45- cells. In pigs, $\mathrm{CD}^{-} 5^{-} \mathrm{CD} 34^{+}$cells have been previously identified in muscle as $\mathrm{PW} 1^{+}$ interstitial cells (PICs) with an ability to differentiate into skeletal myoblast/myotubes, smooth muscle, and endothelial cells (Lewis et al., 2014). The CD45-CD140a ${ }^{+}$cells were also located in the interstitial space of muscle. In normal skeletal muscle and damaged skeletal muscle,

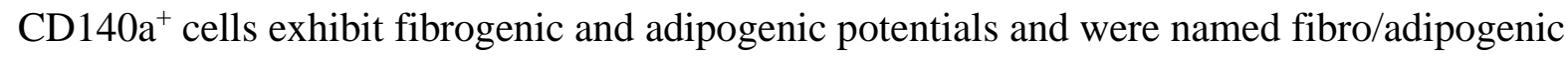
progenitors (FAPs; Uezumi et al., 2010, 2014; Uezumi, Ikemoto-Uezumi \& Tsuchida, 2014). In muscle of growing pigs, we have shown that $\mathrm{CD} 56^{+} \mathrm{CD} 140 \mathrm{a}^{+}$and $\mathrm{CD} 56^{+} \mathrm{CD} 140 \mathrm{a}^{-}$were mainly myogenic (Perruchot et al., 2020). Muscle stem cell heterogeneity has been described at several 
425

426

427

428

429

430

431

432

433

434

435

436

437

438

439

440

441

442

443

444

445

446

447

448

449

450

451

452

453

454

455

other levels, including transcription factor, clonal capacity, metabolism, age dependent myogenic potential, and recently functional response to environmental stress (Cho \& Doles, 2019; Relaix et al., 2021). This multitude of resident stem cells contributes likely together to the remarkable regeneration capacities of muscle after injury (Mackey et al., 2017; Relaix et al., 2021). We also included the CD38 marker in our analysis to determine whether it could be used to identify committed preadipocytes as described in mice (Carrière et al., 2017). However, the very low number of cells expressing this marker does not support these findings. The discrepancy between the two studies may be related to the fact that the CD38 marker was detected in cells from abdominal adipose tissue, an adipose depot exhibiting a greater expression of CD38 than in SCAT.

We highlighted for the first time that the environment influence MSCs in growing pigs. The $\mathrm{CD} 45^{-} \mathrm{CD} 56^{+} \mathrm{CD} 34^{+} \mathrm{CD} 140 \mathrm{a}^{+}$cell population, one of the abundant populations in muscle, increased clearly after an exposure of pigs to poor hygiene of housing conditions. We previously found that $\mathrm{CD}^{+} 6^{+} \mathrm{CD} 140 \mathrm{a}^{+}$cells were myogenic (Perruchot et al., 2020). With the use of the CD34 and CD56 markers, CD34+ cells derived from human muscle were described to be myoadipogenic bipotent progenitors (Pisani et al., 2010a,b). Thus, we can hypothesize that these cells exhibit myo/adipogenic potentials. It is interesting to note that $\mathrm{CD} 56^{+} \mathrm{CD} 140 \mathrm{a}^{+}$cells were also affected by a high-fat/high-fiber diet in porcine muscle (Perruchot et al., 2020). This suggests that these cells may respond to changes of different factors. The current study further indicates that there was an interaction between hygiene conditions and RFI lines for $\mathrm{CD}^{-} 5^{-} \mathrm{CD}^{-} 6^{-}$cells including $\mathrm{CD}^{-} 5^{-} \mathrm{CD} 56^{-} \mathrm{CD} 34^{-}$cells representing a low proportion of cells in muscle. There was a decrease of cells in poor hygiene condition only in LRFI pigs. These cells may be perivascular cells as described for $\mathrm{CD} 146^{+} \mathrm{CD} 34^{-} \mathrm{CD} 45^{-} \mathrm{CD}^{-}$cells in multiple human tissues including muscle (Crisan et al., 2008; Shenoy \& Bose, 2018). These cells may have a myo-adipogenic potential. Indeed, we have shown that $\mathrm{CD}^{-} 6^{-} \mathrm{CD} 140 \mathrm{a}^{+}$cells in porcine muscle exhibited both adipogenic and myogenic potentials (Perruchot et al., 2020). Moreover, Shenoy \& Bose (2018) showed that pericytes from mouse liver were able to regenerate muscle fibers in muscle of dystrophic (Mdx) mice. In addition, it has been shown in skeletal muscle of obese humans that the $\mathrm{CD}^{-} 6^{-}$cell fraction gives rise to white adipocytes (Laurens et al., 2016). Other studies have reported the existence of adipogenic progenitors, not expressing the CD56 marker, in skeletal 
muscle MSCs derived from lean individuals in humans (Vauchez et al., 2009; Lecourt et al., 2010). Altogether, available data obtained in pigs and humans are consistent with a myoadipogenic potential of the $\mathrm{CD}^{-} 5^{-} \mathrm{CD}^{-} 6^{-} \mathrm{CD} 34^{-}$cells.

Adipose tissue cell composition is less complex than skeletal muscle with two abundant CD45cell populations, the $\mathrm{CD}^{-} 5^{-} \mathrm{CD} 56^{-} \mathrm{CD} 34^{-}$and the $\mathrm{CD} 45^{-} \mathrm{CD} 56^{+} \mathrm{CD} 34^{-}$populations. The proportion of $\mathrm{CD}^{-} 5^{-} \mathrm{CD} 56^{-} \mathrm{CD} 34^{-}$cells increased whereas the proportion of $\mathrm{CD} 45^{-} \mathrm{CD} 56^{+} \mathrm{CD} 34^{-}$tended to decrease in degraded hygiene conditions. The presence of $\mathrm{CD} 45^{-} \mathrm{CD} 56^{+} \mathrm{CD} 34^{-}$cells in adipose tissue is poorly documented in the literature. In two previous studies, we provided evidence that $\mathrm{CD} 56^{+}$cells from subcutaneous adipose tissue were less adipogenic than CD56- cells (Perruchot et al., 2013, 2020). Some groups did not find any CD56 ${ }^{+}$cells in adipose tissue, while others attribute the expression of CD56 to natural killer cells $\left(\mathrm{CD} 45^{+}\right)$. Overall, there is no consensus on the expression of the CD56 marker in adipose tissue within the CD45- cells. Moreover, the increase in $\mathrm{CD}^{-} 5^{-} \mathrm{CD} 56^{-} \mathrm{CD} 34^{-}$cells in poor hygiene condition may increase later adipose tissue growth in this group of pigs. Another possible hypothesis would be that the poor hygiene condition of pig housing may lead to a delay in the development of adipose tissue, and therefore

472 the pool of $\mathrm{CD}^{-} 5^{-} \mathrm{CD}^{-} 6^{-} \mathrm{CD} 34^{-}$cells, potential adipocyte precursors, would be less used in these 473 animals compared with those housed in good condition. Altogether, these findings are consistent

474 with studies demonstrating that the composition of the MSC compartment of adipose tissue and 475 skeletal muscle can be affected by several factors including nutritional factors (Perruchot et al., 476 2020) during growth.

\section{Conclusions}

480 The findings gathered in this study clearly show that the relative proportions of hematopoietic 481 and of some MSC populations were affected by hygiene of housing conditions in a tissue482 dependent manner in pigs of both RFI lines. It further indicates that these cell populations may 483 play a significant role in adipose tissue and skeletal muscle homeostasis and can be targeted to 484 modulate growth and body composition in growing animals. Further investigations will be needed to get a better understanding of cell interactions in both tissues. 


\section{Acknowledgements}

489 The authors are very grateful to the staff of the experimental pig facilities from INRAE at UE3P

490 (Saint-Gilles, France) and GenESI (Le Magneraud, Surgères, France) for animal care and

491 slaughtering. They are also grateful to Hélène Gilbert (INRAE, UMR GenePhySe, Toulouse,

492 France) for selection of the pig RFI lines. The authors also wish to thank Frédérique Mayeur and

493 Christine Tréfeu (PEGASE, Saint-Gilles, France) for their contribution to the isolation of adipose

494 and muscle cells.

\section{Funding}

498 The research leading to these results has received funding from the European Union's Seventh

499 Framework Programme for Research, Technological Development and Demonstration (grant

500 number 613574, PROHEALTH project) to support animal costs and from INRAE to support

501 analytical measurements costs. Audrey Quéméner was supported by a $\mathrm{PhD}$ scholarship from

502 INRAE (Phase division) and the research fund of Région Bretagne (France). Funders approved

503 the general objectives of the study but have no roles in its design and data collection nor

504 interfered with data interpretation and conclusions

\section{Data accessibility}

508 Data are available online: https://doi.org/10.15454/IXXVBB

\section{Supplementary material}

512 There is no supplementary material.

\section{Conflict of interest disclosure}

516 The authors of this preprint declare that they have no financial conflict of interest with the 517 content of this article 


\section{References}

Bourin P, Bunnell BA, Casteilla L, Dominici M, Katz AJ, March KL, Redl H, Rubin JP, vascular fraction and culture expanded adipose tissue-derived stromal/stem cells: a joint statement of the International Federation for Adipose Therapeutics and Science (IFATS) and the International Society for Cellular Therapy (ISCT). Cytotherapy 15:641648. DOI: 10.1016/j.jcyt.2013.02.006. abdominal and subcutaneous adipose tissues, and peripheral blood: in vitro characterization and migratory properties in inflammation. Stem Cell Research \&

Carrière A, Jeanson Y, Côté J, Dromard C, Galinier A, Menzel S, Barreau C, Dupuis-Coronas S, Arnaud E, Girousse A, Cuminetti V, Paupert J, Cousin B, Sengenes C, Koch-Nolte F,

537 Chatelet A, Gondret F, Merlot E, Gilbert H, Friggens N, Floc'h NL. 2018. Impact of hygiene of housing conditions on performance and health of two pig genetic lines divergent for

540 Cho DS, Doles JD. 2019. Skeletal muscle progenitor cell heterogeneity. In: Birbrair A ed. Stem 
Biology. Cham: Springer International Publishing, 179-193. DOI: 10.1007/978-3-03024108-7_9.

544 Colditz IG, Hine BC, Colditz IG, Hine BC. 2016. Resilience in farm animals: biology, management, breeding and implications for animal welfare. Animal Production Science

547 Cousin B, Casteilla L, Laharrague P, Luche E, Lorsignol A, Cuminetti V, Paupert J. 2016. Immuno-metabolism and adipose tissue: The key role of hematopoietic stem cells. Biochimie 124:21-26. DOI: 10.1016/j.biochi.2015.06.012.

550 Crisan M, Yap S, Casteilla L, Chen C-W, Corselli M, Park TS, Andriolo G, Sun B, Zheng B, mesenchymal stem cells in multiple human organs. Cell Stem Cell 3:301-313. DOI:

555 De Carvalho FG, Justice JN, Freitas EC de, Kershaw EE, Sparks LM. 2019. Adipose tissue quality in aging: how structural and functional aspects of adipose tissue impact skeletal

De clercq L, Mourot J, Genart C, Davidts V, Boone C, Remacle C. 1997. An anti-adipocyte monoclonal antibody is cytotoxic to porcine preadipocytes in vitro and depresses the

562 Dodson MV, Allen RE, Du M, Bergen WG, Velleman SG, Poulos SP, Fernyhough-Culver M, Wheeler MB, Duckett SK, Young MRI, Voy BH, Jiang Z, Hausman GJ. 2015. Invited 
review: Evolution of meat animal growth research during the past 50 years: Adipose and muscle stem cells. Journal of Animal Science 93:457-481. DOI: 10.2527/jas.2014-8221.

Dominici M, Le Blanc K, Mueller I, Slaper-Cortenbach I, Marini FC, Krause DS, Deans RJ, Keating A, Prockop DJ, Horwitz EM. 2006. Minimal criteria for defining multipotent mesenchymal stromal cells. The International Society for Cellular Therapy position statement. Cytotherapy 8:315-317. DOI: 10.1080/14653240600855905.

574 Girousse A, Mathieu M, Sastourné-Arrey Q, Monferran S, Casteilla L, Sengenès C. 2021. communication? Frontiers in Cell and Developmental Biology 8. DOI:

Han TTY, Walker JT, Grant A, Dekaban GA, Flynn LE. 2021. Preconditioning human adiposederived stromal cells on decellularized adipose tissue scaffolds within a perfusion bioreactor modulates cell phenotype and promotes a pro-regenerative host response. stem cells to livestock growth and development1. Journal of Animal Science 91:57-58. DOI: $10.2527 /$ jas.2012-6103. Selection Evolution 52:60. DOI: 10.1186/s12711-020-00580-4. 
587 Laurens C, Louche K, Sengenes C, Coué M, Langin D, Moro C, Bourlier V. 2016. Adipogenic progenitors from obese human skeletal muscle give rise to functional white adipocytes that contribute to insulin resistance. International Journal of Obesity 40:497-506. DOI: 10.1038/ijo.2015.193.

Le Floc'h N, Knudsen C, Gidenne T, Montagne L, Merlot E, Zemb O. 2014. Impact of feed restriction on health, digestion and faecal microbiota of growing pigs housed in good or

Lee Y, Granneman J. 2012. Seeking the source of adipocytes in adult white adipose tissues. Adipocyte 1:230-236. DOI: 10.4161/adip.20804.

Lefaucheur L. 2010. A second look into fibre typing - Relation to meat quality. Meat Science 84:257-270. DOI: 10.1016/j.meatsci.2009.05.004. skeletal muscle-derived multipotent PW1pos/Pax7neg interstitial cells: isolation, characterization, and long-term culture. STEM CELLS Translational Medicine 3:702712. DOI: https://doi.org/10.5966/sctm.2013-0174. 
Mackey AL, Magnan M, Chazaud B, Kjaer M. 2017. Human skeletal muscle fibroblasts stimulate in vitro myogenesis and in vivo muscle regeneration. The Journal of Physiology

Patience JF, Rossoni-Serão MC, Gutiérrez NA. 2015. A review of feed efficiency in swine: biology and application. Journal of Animal Science and Biotechnology 6:33. DOI: $10.1186 / \mathrm{s} 40104-015-0031-2$. populations to a high-fat/high-fiber diet in skeletal muscle and adipose tissue of growing

Perruchot M, Lefaucheur L, Barreau C, Casteilla L, Louveau I. 2013. Age-related changes in the features of porcine adult stem cells isolated from adipose tissue and skeletal muscle. American Journal of Physiology-Cell Physiology 305:C728-C738. DOI: 10.1152/ajpcell.00151.2013.

Pisani DF, Clement N, Loubat A, Plaisant M, Sacconi S, Kurzenne J-Y, Desnuelle C, Dani C,

628 Pisani DF, Dechesne CA, Sacconi S, Delplace S, Belmonte N, Cochet O, Clement N, C, Dani C. 2010b. Isolation of a highly myogenic CD34-negative subset of human Dechesne CA. 2010a. Hierarchization of myogenic and adipogenic progenitors within human skeletal muscle. Stem Cells 28:2182-2194. DOI: https://doi.org/10.1002/stem.537. skeletal muscle cells free of adipogenic potential. STEM CELLS 28:753-764. DOI: https://doi.org/10.1002/stem.317. 
633

634

635

636

637

638

639

640

641

642

643

644

645

646

647

648

649

650

651

652

653

654

655

Relaix F, Bencze M, Borok MJ, Der Vartanian A, Gattazzo F, Mademtzoglou D, Perez-Diaz S, Prola A, Reyes-Fernandez PC, Rotini A, Taglietti. 2021. Perspectives on skeletal muscle stem cells. Nature Communications 12:692. DOI: 10.1038/s41467-020-20760-6.

Shenoy P, Bose B. 2018. Hepatic perivascular mesenchymal stem cells with myogenic properties. Journal of Tissue Engineering and Regenerative Medicine 12. DOI: 10.1002/term.2503.

Sierżant K, Perruchot M, Merlot E, Le Floc'h N, Gondret F. 2019. Tissue-specific responses of antioxidant pathways to poor hygiene conditions in growing pigs divergently selected for feed efficiency. BMC Veterinary Research 15:341. DOI: 10.1186/s12917-019-2107-2.

Sillence MN. 2004. Technologies for the control of fat and lean deposition in livestock. The Veterinary Journal 167:242-257. DOI: 10.1016/j.tvj1.2003.10.020.

Uezumi A, Fukada S, Yamamoto N, Ikemoto-Uezumi M, Nakatani M, Morita M, Yamaguchi A, Yamada H, Nishino I, Hamada Y, Tsuchida K. 2014. Identification and characterization of PDGFR $\alpha+$ mesenchymal progenitors in human skeletal muscle. Cell Death $\&$ Disease 5:e1186-e1186. DOI: 10.1038/cddis.2014.161.

Uezumi A, Fukada S, Yamamoto N, Takeda S, Tsuchida K. 2010. Mesenchymal progenitors distinct from satellite cells contribute to ectopic fat cell formation in skeletal muscle. Nature Cell Biology 12:143-152. DOI: 10.1038/ncb2014.

Uezumi A, Ikemoto-Uezumi M, Tsuchida K. 2014. Roles of nonmyogenic mesenchymal progenitors in pathogenesis and regeneration of skeletal muscle. Frontiers in Physiology 5. DOI: 10.3389/fphys.2014.00068.

Vauchez K, Marolleau J-P, Schmid M, Khattar P, Chapel A, Catelain C, Lecourt S, Larghéro J, Fiszman M, Vilquin J-T. 2009. Aldehyde dehydrogenase activity identifies a population 
658 Wilschut KJ, Jaksani S, Dolder JVD, Haagsman HP, Roelen BAJ. 2008. Isolation and characterization of porcine adult muscle-derived progenitor cells. Journal of Cellular Biochemistry 105:1228-1239. DOI: https://doi.org/10.1002/jcb.21921.

661 Wilschut KJ, van Tol HTA, Arkesteijn GJA, Haagsman HP, Roelen BAJ. 2011. Alpha 6 integrin is important for myogenic stem cell differentiation. Stem Cell Research 7:112-123. DOI: 10.1016/j.scr.2011.05.001.

664 Wosczyna MN, Konishi CT, Perez Carbajal EE, Wang TT, Walsh RA, Gan Q, Wagner MW, 665 Rando TA. 2019. Mesenchymal stromal cells are required for regeneration and 666 homeostatic maintenance of skeletal muscle. Cell Reports 27:2029-2035.e5. DOI: 10.1016/j.celrep.2019.04.074. 